\title{
CHALLENGES OF EU ACCESSION FOR MACEDONIA AND UKRAINE: SELECTED VIEW FROM INSIDE EUROPE AND OUTSIDE VISEGRAD
}

\section{Amir Imeri*1, Jana Gálová2}

\author{
'State University of Macedonia, Former Yugoslav Republic of Macedonia \\ ${ }^{2}$ Slovak University of Agriculture in Nitra, Slovakia
}

\begin{abstract}
The Former Yugoslav Republic of Macedonia is a country with huge interest in accession to the great family of the European Union, which now counts about 500 million people. The paper aims to explain this interest and to give detailed arguments to all the expectations, by focusing on the process of accession of the country to the European Union and giving examples of other countries' similar efforts from wider region. This process represents the culmination of more than two decades of economic, social and political transformation of the country. The membership in the European Union, according to the theoretical knowledge and comparative experience, should bring convenience for Macedonia and its citizens, including prosperity, more intensive relations with its European neighbours and contribution to shaping the political, social and economic development of Europe. The accession process is long and difficult, partly because of the necessity to adopt many laws and regulations of the European Union for new member states, contained in the Acquis communautaire.
\end{abstract}

Keywords: European Union, the Former Yugoslav Republic of Macedonia, accession, Stabilization and association agreement, Acquis communautaire

\section{Introduction}

Many political and economic events have influenced the development of countries throughout Europe, especially in the past several years (Kotabe and Helsen, 2010). Due to the unstable political situation, it is essential to continuously monitor the environment, analyze the situation, and try to estimate the degree of possible political risk (i.e. the extent of possible political changes) in a particular country (Horská, Nagyová and Felixová, 2010). Lesser developed countries and emerging markets pose particularly high political risks, even when they have been following reforms to solve the political problems they have (Doole and Lowe, 2008).

In the official EU documents, the Republic of Macedonia is referred to as "the former Yugoslav Republic of Macedonia" (abbreviated FYROM) due to a dispute over the country's name, which is identical to a Greek province (Euractiv.com, 2010). FYROM, from its peaceful separation from the dissolving Socialist Federal Republic of Yugoslavia, declared independence on 8 September 1991, and immediately expressed interest in integration in the European Union (in that time called the European Community). After 2 years of embargo by Greece (1993-1995), the goal was achieved only in 1995 by establishing the first diplomatic relations with the EU. Since 1996, the country became eligible for funding under the European Commission's pre-accession PHARE programme (European Commission, 2012). The PHARE programme was the EU's main financial instrument to assist Central and Eastern European Countries (CEECS) during the run-up to the 2004 enlargement. As of 2001, CARDS replaced PHARE for the countries of the Western Balkans (Euractiv.com, 2010).

In June 2000, the European Council meeting at Santa Maria de Feira in Portugal recognised Western Balkan countries that have signed a Stabilisation and Association Process (SAP) with the EU as ,potential candidates' for EU membership. Following the successful conclusion of the negotiations at the Zagreb Summit of 24 November 2000, FYROM was the first country in the
Western Balkans to sign the Stabilisation and Association Agreement (SAA) on 9 April, 2001 in Luxembourg. An Interim Agreement (IA) was also signed on the same day; with the IA the Parties allowed trade and trade-related matters of the SAA to enter into force (Delegation of the EU, 2014a). SAA was ratified by the Macedonian Parliament on 1 June, 2001, and entered into force on 1 April, 2004, following its ratification by all member states.

One of the biggest reforms in FYROM was Ohrid Framework Agreement from August 2001. This agreement was formed after an internal conflict in spring 2001 and brought solutions to many difficult issues between ethnic communities in the country. SAA resulted in two major benefits. Politically, it made FYROM a potential member of the EU and economically enabled joining to the free trade zone of the EU, bringing benefits from asymmetric trade preferences with the EU. The signing of the SAA also helped the Macedonian economy in restructuring and adjustment to new conditions within social and economic development.

The Thessaloniki Summit in June 2003 is considered to be a historic one as for the first time in the history of the European Union, a mini-summit called 'EU - Western Balkans Summit' was held in the framework of the summit (Delegation of the EU, 2014a).

Reforms undertaken within the SAA paved the way for FYROM to submit its formal application for the EU membership on 22 March, 2004. In May 2004, the European Council asked the Commission to give its opinion on the country's application. In 0ctober 2004, it received an EU questionnaire, which was completed at a fast pace and handed in February 2005. The first favourable opinion for accepting FYROM in the EU was published in November 2005 and one month later, the European Council decided to grant the country candidate status (European Commission, 2012).

In 2009, the European Commission proposed to grant visa liberalisation to the citizens of former Yugoslav Republic of Macedonia, Montenegro and Serbia to the Schengen area. In the end of the year, the Commission estimated that the country sufficiently fulfilled the political criteria and 
recommended the opening of accession negotiations. This recommendation was reiterated by the Commission in 2010, 2011, 2012 and 2013. As for a candidate country, FYROM needed only to get a date for starting accession negotiations with the EU. Unfortunately, this decision has been delayed for more than 5 years and is still ongoing. Although in regular reports issued by the European Commission from 2006 to 2013 progress on reforms was recognized, one of the main preconditions of the EU accession remains the political problem of resolution of the name dispute with Greece (Euractiv.com, 2010).

\section{Material and methods}

To research the proposed topic we applied several scientific research methods of quantitative analysis (based on the use of descriptive models) and qualitative methods of analysis, synthesis and comparison (Kleinová, 2013). The paper largely relies on empirical research about the impact of the Stabilization and Association Agreement (SAA) to the economy of FYROM. For the purposes of analysis, the data about current trends in the economies of new member states of the European Union are also used, from different related resources, especially from main European economic institutions, the European Commission, official documents and reports of the European Union (EU) and the State Statistical Office of the Former Yugoslav Republic of Macedonia (SSOF).

\section{Results and discussion}

The close geographical connection among countries in Central and Eastern Europe gives opportunities for regional cooperation and for the establishment of international relations (Gálová, 2013). Similarities due to common historical, political and cultural background form a base for better understanding of development processes (Horská, 2014). The paper contributes to the evaluation of economic effects of the accession of the Former Yugoslav Republic of Macedonia (FYROM) to the European Union. The process of starting negotiations for the EU integration will significantly affect the future development of the country's transition.

\section{Macroeconomic convergence}

The Former Yugoslav Republic of Macedonia has fulfilled the Copenhagen economic criteria. The country has a functioning market economy, but differs in the second sub-criterion, the ability to cope with competitive pressures of the EU single market. Real convergence of FYROM lags far behind the EU new member states (NMS). Although GDP growth in the country has accelerated in recent years (except in 2009 and 2012 where it recorded negative rates), it is a source of concern. The rate of investment was on average less than $21 \%$ of GDP, the small growth of Gross fixed capital formation (GFCF) influenced impossible convergence of income per capita with the EU members. According to the World Bank, the Gross fixed capital formation (GFCF; formerly gross domestic fixed investment) includes land improvements (fences, ditches, drains, and so on); plant, machinery, and equipment purchases; and the construction of roads, railways, and the like, including schools, offices, hospitals, private residential dwellings, and commercial and industrial buildings. According to the 1993 system of national accounts (SNA), net acquisitions of valuables are also considered capital formation (World Bank, 2014b).

If FYROM is not able to increase the share of GFCF over $25 \%$, it will be forced to rely entirely on productivity to catch up with the level of income per capita of the EU member states. A rapid growth in GDP will cause structural changes and the transfer of labour from agriculture to industry and services.
The country must be prepared for social and critical tasks and strategic options for socio-economic convergence after starting the negotiations with the EU.

Integration could increase inflows of FDI and faster growth will cause higher inflation. The current exchange rate regime will be under pressure and will have to be revised. Taking into consideration the low level of prices and income per capita between FYROM and the EU, the adjustment of prices will be an important source of inflationary pressure, therefore from now on the prices need to be gradually adapted, also to avoid problems in meeting the Maastricht criteria in terms of inflation at the time of accession (Brada, 2009). The country should work harder to achieve higher growth rates, so that the country could be a more attractive candidate for the EU membership.

Prudent macro policies should be followed combined with businessfriendly reforms, promoting investment in fixed capital formation. The country needs to create more space for strategic planning, research and development and reduce administration costs. Such capabilities will be critical in getting all available EU funds and their effective utilization (Poposki, 2013).

FYROM should aim not only to join the EU, but also to quickly enter the Eurozone, and that means working towards the fulfillment of the Maastricht criteria even before accession. If the country had been in the ERM 2 in the past few years, it would certainly have met the criteria for the stability of the exchange rate for the euro adoption, since the Denar is fixed to the euro, and in recent years it did not pass the fluctuating limit $\pm 15 \%$ with the euro rate. Over the past few years, with the exception of inflation growth in 2007, FYROM was also very close to meeting the Maastricht criterion for inflation. The adoption of the euro should affect the growth of trade with other eurozone members. The country can also expect a rise in FDI, even before the adoption of the euro (SSOF, 2014). The kind of exchange rate regime to follow before integration depends on how quickly the new member state wishes to adopt the euro as its own currency. If the Maastricht criteria are met, then the minimum period will be two years spent in ERM 2 regime.

FYROM should seriously strengthen the absorption capacity to use the EU funds in order to receive all the possible assistance in the period before accession to the EU, and especially after membership where it will be able to get significant amounts of larger EU funds (European Commission, 2013b). The ability to effectively use the EU funds does not depend only on the central government, but all levels of governance must strengthen and develop the capacity to apply and use the EU funds. NGOs, schools, universities, and individuals such as teachers and students of agriculture should also help in developing the capacity to apply and use the available EU funds. If administrative absorption capacity is not set at an appropriate level, the country can even become a net contributor to the EU budget in the early postaccession period, i.e. will receive less from the EU budget than with what it contributes to.

\section{Fiscal effects of the EU accession}

FYROM should be systematically prepared for the fiscal costs of the EU accession, which are to become higher because of contributions to the EU budget after becoming an EU member. The introduction of the acquis is associated with an increase in some categories of spending of national budget, such as for Schengen, transportation, agriculture, environment, etc.; while on the revenue side, the EU membership will affect the reduction of certain categories, such as customs. Setting the tax system with the EU standards will require some changes in the amount and structure of tax revenues (SSOF, 2012). The impact of fiscal adjustments on customs duties will be negative, because it will have to eliminate customs duties for other members after the accession (most have already been eliminated) and apply a Common Customs Tariff to non-EU countries (which on average is lower than 
the current customs duties in the country). On the other side, the adjustment of excise duties on cigarettes and energy sources (electricity, natural gas and oil) will increase fiscal revenues.

Taking all this into consideration, during the first three years of the EU membership, FYROM can expect positive net effect on the economy, because of the rule that a country cannot be net lender in the initial period.

\section{International trade and foreign direct investments}

FYROM should continue with the liberalization of foreign trade, in line with the Stabilization and Association Agreement (SAA) with the EU. The short term effect from the EU membership on foreign trade volume will not be huge. The country should increase agricultural trade with the EU before accession, through supporting the investments in the food industry (Delegation of the EU, 2014b). It should raise the quality of agricultural production to meet the EU standards. This will allow having competitive food products, generating higher added value in the economy. Also, it should strive to negotiate favourable production quotas with the EU on appropriate agricultural commodities. Food prices may rise moderately after joining the EU. With the progress in negotiations on accession to the EU, FDI inflows in the manufacturing sector will increase. FDI is expected to achieve diversification of the current industrial base. Since the country will succeed in attracting FDI and accelerate GDP growth, Denar will face a high-pressure growth in value. Macedonian current exchange rate regime could become unsustainable and inconsistent for maintenance of low inflation, which is a prerequisite for adoption of the euro in the future.

FYROM must seek faster growth in GDP from higher investments and higher engagement with the world economy, especially with the neighbouring countries of Southeast Europe and the EU. It should continue with market-friendly reforms to improve the business climate and attract more foreign investments.

\section{Industry and non-financial services}

Macedonian industry and industrial exports are less diversified than NMS; therefore the country should promote diversification. The country should support the modernization and upgrade its major established sectors such as textiles and metal products.

FYROM currently spends constantly very little on Research and Development (R\&D) and other activities related to innovation, from $0.22 \%$ of GDP in 2003 to only $0.24 \%$ (estimated data) in 2011 (SSOF, 2014). This is contrary to the strategy "Europe 2020" with the objective of achieving the cost of R\&D on the level $3 \%$ of GDP. To strengthen the country's ability in using and adapting new technology, costs of R\&D should increase, in both developed and potential industries. This requires strengthening of $R \& D$ capacities in universities and research institutes.

The country should increase and restructure infrastructure costs for transport in order to increase the role of road transport in the last two decades. Tourism has great potential for the country and it should aim to raise the number of visitors further. NMS due to accession to the EU were forced to reduce their costs of state aid from $1.5 \%$ of GDP to $0.5 \%$, and it is expected also from FYROM to have the same pressure, which rose to about $2.5 \%$ of GDP in recent years.

\section{Agriculture and regional development}

Agricultural employment fell from $20.1 \%$ in 2006 to $17.3 \%$ in 2012, a figure similar to that of Poland $(17.9 \%)$ and Lithuania $(15.6 \%)$ at the time of accession, but significantly less than that of Romania (30.6\%) and Bulgaria (19.4 \%) in 2007 (European Commission, 2013b). Currently, agricultural employment in FYROM is high, because it serves as a social amortizer, helping to alleviate poverty and unemployment. Growth in the rest of the economy is a major mechanism in reducing the over-employment in agriculture. Experience from NMS shows that within the EU-28, trade increased rapidly after their membership, especially among the NMS, since their borders disappeared within the single market of EU-28. FYROM is predominantly an importer of agricultural products, with the exception of certain products such as vegetables, lamb, wine and eggs in some years. The wine sector is particularly important, as it is one of the main export products.

According to the national strategy of the Ministry of Agriculture of FYROM, financial support in agriculture in 2013 was 135 million euro, in the second year it will increase to 140 million and in the next three years up to 150 million euro (Imeri, 2013).

Specific initiatives for rural development will help FYROM after becoming an EU member state, where agriculture has an important share of employment, to restructure its agricultural and rural sector. The investments will improve the living conditions in rural areas and adopt a variety of sources of rural income, and assist in raising revenue in the joint development of agricultural standards.

The large number of unemployed people in the country allows keeping wages and production costs relatively low, allowing the Macedonian goods to access foreign markets easier, including the EU as a major market for foreign trade. The EU membership is expected to make losses for consumers and benefits for producers of agricultural commodities. Participation in CAP is expected to result in increased food prices. However, a slight increase in food prices will be replaced by a significant increase in revenues for farmers. In case of Macedonian accession to the EU, the implementation of CAP payments will have a significant impact on agricultural income. In general, large companies in the NMS have used these CAP programs (Brada, 2009). This danger also exists in FYROM; therefore the Government should develop programs to help small farms to access these funds. Government should also provide technical assistance to farmers and food processors to apply for these funds and to reduce administrative burdens in accessing these payments. More than half of the farm households have an area less than 1 ha and these farms will not benefit from the EU payments if the same procedures are applied as they were in NMS, where the threshold was set on 1 ha. Lower threshold would reduce inequality, but would increase administrative costs.

The expectation of accession to the EU brought improvements in the functioning of rural land and capital markets, and practice has shown that this process is enhanced by membership to the EU. A huge benefit of membership to the EU for farms in the NMS was better access to capital from higher direct subsidies and from banks that were more willing to give loans to farms. In return, this increased the profits. At the same time, the price of land was growing significantly, reflecting the improvement of profitability, productivity and farm subsidies that are related to land use. FYROM should expect similar effects.

Prices for rental and sale of land are expected to increase dramatically in FYROM after the EU integration. As in other connections, the EU will determine the activities that the Government needs to do in order to meet the requirements for the EU accession. The most important constraints facing agriculture and rural development in the country are broader structural problems in both production and rural markets (European Commission, 2012).

In order to reduce rural poverty, the policies of the Government of FYROM should be directed to the improvement of education and professional qualification for employment in better jobs (outside farms). Government 
of FYROM should consider the experience of countries such as Poland and Romania, which used "schemes for early retirement" to motivate older farmers to stop their agricultural activities and to lease their land.

Also, there is a need for sufficient and well-trained staff to meet the EU requirements related to payments of the CAP (0J EU, 2010a). The government also needs to tighten controls over the EU subsidies. Accession of FYROM to the EU will allow liberalization of the labour market, which will contribute to the exodus of labour to rural areas in search of better job opportunities and higher incomes in the old EU member states. The most important public programs that require additional funding are irrigation, consulting services and applied agricultural research.

\section{Financial services and capital flows}

After the integration of FYROM in the EU, the financial institutions from the other EU member states will expand their activities in the country, which will lead to concentration of the banking sector. This will contribute to the improvement of its efficiency and growth of confidence, but will also bring added risks. A key risk is credit expansion caused by relaxed lending standards, which will eventually lead to asset price bubbles. The situation after the entry into the EU will thus be very difficult for regulation and supervision of the financial system.

FYROM should review and strengthen the existing framework for dealing with weak institutions and systemic crises before the EU membership. Another important tool that should be available to the Macedonian authorities is the power to limit the transfer of profits to shareholders. The authorities also need to be able to ask shareholders to retain the profit or increase the regulatory capital of banks, if it is confirmed that it is necessary to ensure the stability of the institution.

In future, bank deposits may be reduced compared to the demand for loans, and policy makers need to find a new system of housing finance as soon as possible. One possibility is securitization (purchase or sale of securities), and the other is to promote the bond market.

Policymakers should be prepared for pressures in real convergence by the EU membership. If pressure occurs in real appreciation, currency revaluation should be considered or leaving the de-facto pegging in favour of floating regime.

Household loans in foreign currency (or indexed to foreign currencies) should be followed and discouraged. To promote long-term savings a system for financing of households and sources of funding should be developed. If Macedonian authorities support private savings for households, they do not need to create specialized institutions.

Building national financial supervisory system within the Central Bank should be a priority for FYROM, even before accession to the EU (World Bank, 2014b). Such a system should focus on systemic risk, increasing the mutual exchange of information, providing strong technical and professional support, and obtaining independent and apolitical decisions. Macedonian banking sector regulator should develop a comprehensive framework for regulating the management of liquidity of local banks, including tools for potential restrictions on cross-border liquidity during the times of financial crises.

\section{Labour market}

The biggest problem in the Macedonian labour market is the huge number of unskilled workers, who are difficult to employ without government intervention. Shortages of skills limit employment growth. Reforming vocational education after consulting the companies should be a priority. However, it is vital to do a research for the needs of companies for employees' skills. Tax policies should be implemented that will make part-time work more attractive to employers, e.g. continuing the government measure adopted in February 2014 for exemption in payments regarding social security in the first year for employers in private sector who hire young people up to 29 years old, registered as unemployed at the Employment Agency of FYROM (Delegation of the EU, 2014b). These active labour market policies (ALMP) should be mainly aimed at the young generation, new entrants to the labour market, which probably would have been able to benefit from them. Temporary direct job creation by the government, often called public works, is ineffective because it does not make employees able to find a regular employment after the end of contract.

It is also important to establish a good system for tracking unemployment rate given that the vast majority of the unemployed are longterm unemployed. This latter group should be monitored because they may be employed in informal work. Therefore, proper functioning of public service recruitment (PSR) improves the efficiency of the labour market.

\section{Cooperation of FYROM with V4 countries}

The Visegrad countries are among the strongest supporters of the EU-Balkan enlargement. They are excellent examples for FYROM to pick up good practices and try to implement them at national and local level. Representatives of Balkan states have been regularly invited to Visegrad+ ministerial meetings. In the past 20 years, it was important in the Balkan regional cooperation to have as many meetings with the counterparts in Central Europe as possible, because most of the Western Balkan countries used to be in armed conflict or had very conflicted and complex situations.

Specific contributions of the V4's individual members can be named. Under the Czech EU presidency, FYROM moved forward especially on visa liberalization with the EU. Poland has been helpful, for example, under the so-called Utrecht process in sharing know-how on justice and home affairs and public administration reform. With Hungary, FYROM benefited on the implementation of Schengen acquis in the country. Also Slovakia has been very supportive, thanks to high level of people knowledgeable about the Balkan in the EU institutions - such as the European Parliament member Eduard Kukan and Miroslav Lajčák, former managing director for SouthEastern Europe at EEAS.

Slovakia can be taken as an example of transformation, attraction of foreign investments, and its success story to be implemented in FYROM. Also, for FYROM it is of huge importance to strengthen further economic cooperation with the Visegrad group (made up by the Czech Republic, Poland, Slovakia and Hungary), not just to increase the economic cooperation between the countries, but also because this group is very influential in the $\mathrm{EU}$; the voting rights of these four countries are equal to the voting rights of Germany and France combined.

The share of increase of product export of FYROM towards the Visegrad countries have increased for the period $2010-2013$ by $62 \%$, while the increase of import of products from the same countries have also increased by $46 \%$ (SSOF, 2012).

\section{Selected views on the association process of Ukraine to the EU}

The enlargement of the EU in 2004 with Central and Eastern European countries, but also in 2007 with East-South European Countries, has become a strong impulse to intensify competition in all business areas and led to changes in relationships between the EU and other countries (Wach, 2012). The EU has even enlarged to 28 member states in 2013. Today, the boundary line on the Eastern side of the enlarged European Union remains 
a key site in the geopolitics of Europe, when this area represents the sense of being closer to Europe but at the same time a real border by the EU itself (Szmagalska-Follis, 2008).

Ukraine has chosen European integration as its strategic priority and was aiming to create preconditions to meet requirements enabling joining the EU. The country's accession to the WTO in 2008 meant the liberalization of the trade regime between Ukraine and the $\mathrm{EU}$ - at the same time, it was a small step towards the associate membership.

On the other hand, a lot of other factors (not only economic, but also demographic) prevent Ukraine's accession to the EU - it lags behind in the development of science and engineering, industry, main social indicators and with its numerous population it cannot be so rapidly integrated into the EU as small Central European countries.

In 2011, negotiations between Ukraine and the EU about the Association Agreement (AA) were concluded. As a part of it, the agreement about the Deep and Comprehensive Free Trade Area (DCFTA) has been prepared, which would offer Ukraine a framework for modernising its trade relations and for economic development by opening markets via progressive removal of customs tariffs and quotas, and by an extensive harmonisation of laws, norms and regulations in various trade-related sectors, creating the conditions for aligning key sectors of the Ukrainian economy to the EU standards (European Commission, 2013a). However, it is pending signature from 2013.

Ukraine's orientation towards the EU accession prevents to develop international relations within the framework of the CIS (mainly with Russia) and it is quite evident that it is impossible at the same time to be both in economic union with Russia (or in Eurasian Economic Community) and in the EU (Zhemoyda, 2008).

The Visegrad countries are also in this case interested in Ukraine's successful European integration, as it would bring enhanced trade development. The failed first attempt to sign the AA in Vilnius in November 2013 caused unexpected range of protests throughout Ukraine and the situation now is an example of political uncertainty and instability.

Differences in the size of economies and size of markets, with different current political, economic, social and legal frameworks in every analysed country continue to have great impact on relations, however, the localisation of individual countries within the framework of Europe and of the EU is a feature to be used for mutual benefit of all parties.

\section{Conclusions}

The dynamism of Central and Eastern European countries economic development enables us to state that without any doubts, this territory and these countries have been continuously improving their positions within the scope of the globalisation process and mutual relations.

Integration of the Former Yugoslav Republic of Macedonia in the European Union as a full member country will have huge impact on its economy. The main reason is the changes that the country needs to make before entering the EU - mainly the political criteria. In order to start the negotiations, it will have to adopt the acquis that contains 35 chapters. The other reason is that it will get reputation worldwide, by participating in all EU institutions and being equal to the high quality products that the older EU member states have worldwide. The economic effect will be seen more in a long run, as it will make a positive impact in the economy of the country and will bring many changes. FYROM needs to do more for highly skilled labour, because people will look for better jobs after the EU integration, but not immediately, as of experience from NMS is to wait 7 years for free movement of labour to the other EU member states. The economic cooperation of FYROM and the Visegrad countries should be developed further, since the potential is very high in different fields, especially in mountain tourism, village tourism, health tourism, etc.

\section{References}

BRADA, J. et al. 2009. Convergence to the European Union: Challenges and Opportunities. 113 p. ISBN 978-9989-188-61-9 [2014-08-22]. Available from: http://www.finance. gov.mk/files/u9/Convergence_Study_final.pdf

DELEGATION OF THE EUROPEAN UNION to the Former Yugoslav Republic of Macedonia. 2014a. Chronology of bilateral relations. [2014-08-20]. Available from: http://eeas. europa.eu/delegations/the_former_yugoslav_republic_of_macedonia/eu_the_ former_yugoslav_republic_of_macedonia/chronology/index_en.htm

DELEGATION OF THE EUROPEAN UNION to the Former Yugoslav Republic of Macedonia. 2014b. Political \& economic relations. [2014-08-20]. Available from: http://eeas. europa.eu/delegations/the_former_yugoslav_republic_of_macedonia/eu_the_ former_yugoslav_republic_of_macedonia/political_relations/index_en.htm

DOOLE, I. - LOWE, R. 2008. International Marketing Strategy: Analysis, Development and Implementation. $5^{\text {th }}$ ed. London : Cegage Learning EMEA, 2008. 462 p. ISBN 978-184480-7635.

EURACTIV.COM. 2010. EU-Macedonia relations. Published 15.03.2010, updated 21.10.2010. [2014-08-21]. Available from: http://www.euractiv.com/enlargement/ eu-macedonia-relations-linksdossier-329923

EUROPEAN COMMISSION. 2012. Commission Staff Working Document: The Former Yugoslav Republic of Macedonia - 2012 Progress Report, Accompanying the Document Communication from the Commission to the European Parliament and the Council, Enlargement Strategy and Main Challenges 2012-2013 \{Com(2012) 600 Final\}. Brussels. 10.10.2012. 70 p. [2014-08-21]. Available from: http://ec.europa.eu/ enlargement/pdf/key_documents/2012/package/mk_rapport_2012_en.pdf

EUROPEAN COMMISSION. 2012. The former Yugoslav Republic of Macedonia. [2014-0821]. Available from: http://ec.europa.eu/enlargement/countries/detailed-countryinformation/fyrom/index_en.htm

EUROPEAN COMMISSION. 2013a. EU - Ukraine Deep and Comprehensive Free Trade Area. [2014-01-24]. Available from: http://trade.ec.europa.eu/doclib/docs/2013/april/ tradoc_150981.pdf

EUROPEAN COMMISSION. 2013b. Report from the Commission to the European Parliament and the Council the Former Yugoslav Republic of Macedonia: Implementation of Reforms within the Framework of the High Level Accession Dialogue and Promotion of Good Neighbourly Relations. COM (2013) 205 final. 16.04.2013. Strasbourg. 13 p. [2014-08-21]. Available from: http://ec.europa.eu/enlargement/pdf/key_ documents/2013/mk_spring_report_2013_en.pdf

GÁLOVÁ, J. - HORSKÁ, E. 2013. Sustainability in Business: Global Challenges in International Business. In HORSKÁ, E. - YESPOLOV, T. I. et al. 2013. Sustainability in Business and Society: Global Challenges - Local Solutions. Kraków :Wydawnictwo Episteme, 2013. pp. 111-132. ISBN 978-83-7759-015-7.

GÁLOVÁ, J. 2013. Opportunities for Doing Business with Countries Neighbouring V4 - The Case of Ukraine. In Entrepreneurial Business and Economics Review, vol. 1, 2013, no. 1, pp. $77-90$

HORSKÁ, E. - NAGYOVÁ, L. - FELIXOVÁ, I. 2010. CAGE distance framework among Visegrad countries, Ukraine and Russia and lessons for international business. In BIELIK, P. et al. 2010. Economics, Social Policy and Citizenship in the European Union : Evidence of V4 Countries and Perspectives for Ukraine. Nitra : SUA, 2010. pp. 54-98. ISBN 97880-552-0448-2.

HORSKÁ, E. 2007. Medzinárodný marketing. Nitra : SPU, 2007. 223 s. ISBN 978-80-8069938-3.

HORSKÁ, E. 2014. International Marketing : Within and Beyond Visegrad Borders. Krakow : Wydawnictwo Episteme, 2014. 312 p. ISBN 978-83-7759-039-3.

IMERI, A. 2013. Effects upon foreign trade of FYROM after free trade agreement with EFTA countries. In Proceedings of the 5th International Conference, The Economies of Balkan and Eastern Europe Countries in the Changed World'. 9-12 May 2013. Istanbul : Kavala Institute of Technology, 2013. pp. 81-91. ISBN 978-960-363-043-2. ISSN 1792-4383.

KLEINOVÁ, K. 2013. Current situation and trends in marketing research. In Business management - practice and theory in the $21^{\text {st }}$ century. Nitra : SUA, 2013. p. 85-91. ISBN 978-80-552-1024-7.

KOTABE, M. - HELSEN, K. 2010. Global marketing management. $5^{\text {th }}$ ed. Hoboken, NJ : Wiley, 2010.725 p. ISBN 04-703-8111-6. 
KRETTER, A. a i. 2010. Marketing. $4^{\text {th }}$ ed. Nitra : SPU, 2010. 287 s. ISBN 978-80-5520355-3.

OFFICIAL JOURNAL OF THE EUROPEAN UNION. 2010a. Consolidated version of the Treaty on the functioning of the EU: (38, vol. 53, 16. 02. 2010. ISSN 1725-2423. DOI: 10.3000/17252423.C_2010.038.eng. [2014-08-18]. Available from: http://eur-lex. europa.eu/legal-content/EN/TXT/?uri=0):C:2010:038:TOC

OFFICIAL JOURNAL OF THE EUROPEAN UNION. 2010b. Consolidated version of the Treaty on the functioning of the EU: (47, vol. 53, 25. 02. 2010. ISSN 1725-2423. DOI: 10.3000/17252423.C_2010.047.eng. [2014-08-18]. Available from: http://eur-lex. europa.eu/legal-content/EN/TXT/?uri=0J:C:2010:047:TOC

PALUCHOVÁ, J. - BENDA PROKEINOVÁ, R. 2013. Udržatel'né tendencie v spotrebitel'skom správaní: Asociačné pravidlá, udržatel'ný marketing a zodpovedná spotreba. Nitra : SPU, 2013. 112 s. ISBN 978-80-552-1125-1.

POPOSKI, N. 2013. Building a Community of Stable and Prosperous States - the Unfinished "Mission" of the EU in the Western Balkans. In 20 Years that Changed Europe: The Copenhagen Criteria and the Enlargement of the European Union. Conference Report. Copenhagen. 14 May 2013. pp. 21-23. [2014-08-20]. Available from: http:// um.dk/da/ /media/UM/Danish-site/Documents/Politik-og-diplomati/Nyheder-ogpublikationer/20\%20Years\%20that\%20Changed\%20Europe_UM.pdf

STATE STATISTICAL OFFICE of the Former Yugoslav Republic of Macedonia. 2012. Foreign trade. [2014-08-14]. Available from: http://www.stat.gov.mk/Oblast0psto_ en.aspx?id=23

STATE STATISTICAL OFFICE of the Former Yugoslav Republic of Macedonia. 2014. Macedonia in figures 2013. Skopje, 87 p. Available from: http://www.stat.gov.mk/ Publikacii/MK_Brojki_2013_a.pdf

STATE STATISTICAL OFFICE of the Former Yugoslav Republic of Macedonia. 2013. Tourism and Catering. [2014-03-05]. Available from: http://www.stat.gov.mk/Oblast0psto_ en.aspx?id=25
STATE STATISTICAL OFFICE of the Former Yugoslav Republic of Macedonia. 2011. Изв03 според сектори и отсеци на СМТК Рев.4", [2014-04-06]. Available from: http:// www.stat.gov.mk/0blast0psto.aspx?id=23

SZMAGALSKA-FOLLIS, K. 2008. Repossession: Notes on Restoration and Redemption in Ukraine's Western Borderland. In Cultural Anthropology, vol. 23, 2008, no. 2, pp. 329-360.

WACH, K. 2012. Internationalization Strategies for SMEs. In DASZKIEWICZ, N. - WACH, K. 2012. Internationalization of SMEs. Context, Models and Implementation. Gdańsk : Gdańsk University of Technology, 2012. pp. 40-62. ISBN 978-83-7348-411-5.

WORLD BANK. 2014a. Gross fixed capital formation. [2014-04-06]. Available from: http:// data.worldbank.org/indicator/NE.GDI.FTOT.CD

WORLD BANK. 2014b. World Development Indicators. [2014-04-06]. Available from: http://data.worldbank.org/country/macedonia-fyr

ZHEMOYDA, 0. 2008. Regional Development of Rural Areas in Ukraine and Other Central and Eastern Europe Countries. In BIELIK, P. - KLEPACKI, B. - KVASHA, S. Agricultural market and trade: evidence and perspective of $\mathrm{V} 4$ region and its neighbour - Ukraine: Visegrad Fund. Warszawa : Wieś Jutra, 2008. pp. 90-104.

\section{Contact address:}

Amir Imeri, Faculty of Economics, State University of Tetova, Rruga e llindenit pn, 1200 Tetovo, Former Yugoslav Republic of Macedonia, 푤 +38 9775253 30, e-mail: amirimeri@yahoo.com 